\title{
Dreaming on Latin America: Reflections on Russian Diplomacy in the Region
}

\author{
V.L. Jeifets \\ St. Petersburg State University, Saint-Petersburg, Russian Federation
}

\begin{abstract}
The article contains an outline of evolution of so-called Russian "return" into Latin America. The author tries to analyze how Russian foreign policy towards the Latin American and Caribbean region over the last three decades pointing some its key features and trying to define existing obstacles for its implementation, and to make some conclusions about possible prospects for Russia's position in the region facing new challenges. Based on a literature and media review and a survey of documents and available statistical data, as also on the analysis of official statements, the aim of this article is to contribute towards a more profound understanding of Russia's policy in Latin America. The extension of the article doesn't permit to make a thorough research of all the details of Moscow's return to the continent; however, the author will refer to Venezuelan case at the contemporary stage as one of the important issues for Russian policy. The crisis in Venezuela proves to be a test for Russia: is it able to maintain an influential actor in Latin America or not. To sum up, this case is important in the context of this article as it shows if Russian diplomacy in Latin America is really new or it is a re-edition of Soviet policy toward the region.
\end{abstract}

Key words: Latin America and the Caribbean, Russia, foreign policy, Venezuela, China, USA, BRICS

Acknowledgements: The article was prepared as part of the research grant provided by the Russian Foundation for Basic Research (RFBR), Grant No. 19-014-00042 (Latin America in the New World Order: Perspectives and challenges).

The author would like to express his gratitude to Vladimir Rouvinski and Andres Serbin for fruitful discussions on the topic of the article.

For citation: Jeifets, V.L. (2020). Dreaming on Latin America: Reflections on Russian Diplomacy in the Region. Vestnik RUDN. International Relations, 20 (3), 521-533. DOI: 10.22363/2313-0660-2020-20-3-521-533

\section{Мечтая о Латинской Америке: размышления о российской дипломатии в регионе}

\author{
В.Л. Хейфец \\ Санкт-Петербургский государственный университет, Санкт-Петербург, Российская Федерация
}

В статье представлена схема эволюции так называемого «возвращения» России в Латинскую Америку. Автор анализирует, как изменилась российская внешняя политика в отношении региона Латинской Америки и Карибского бассейна за последние три десятилетия, указывая на некоторые ее ключевые особенности, и рассматривает существующие препятствия для реализации российских внешнеполитических интересов, а также делает некоторые выводы о возможных перспективах положения России в регионе в условиях новых вызовов, с которыми сталкивается континент в последние годы. Основываясь на обзоре литературы и

(C) Jeifets V.L., 2020

This work is licensed under a Creative Commons Attribution 4.0 International License.

https://creativecommons.org/licenses/by/4.0/ 
средств массовой информации, на документах и доступных статистических данных, а также на анализе официальных заявлений первых лиц России и стран Латинской Америки и Карибского бассейна, автор проводит глубокий анализ политики России в Латинской Америке. При этом в статье не ставится задача изучения всех деталей возвращения Москвы на континент. В качестве исследовательского кейса автор прибегает к рассмотрению событий в Венесуэле, которые позиционируются как один из наиболее важных вопросов российской политики в регионе на современном этапе. Кризис в Венесуэле стал испытанием для России, поставив вопрос о том, сможет ли она сохранить роль влиятельного игрока в Латинской Америке или окончательно утратит эту роль. Данный случай также показывает, действительно ли российская дипломатия в Латинской Америке является новой или же представляет собой несколько измененную модель советской политики в отношении региона.

Ключевые слова: Латинская Америка и Карибский бассейн, Россия, внешняя политика, Венесуэла, Китай, США, БРИКС

Благодарности: Статья подготовлена в рамках исследовательского гранта Российского фонда фундаментальных исследований (РФФИ), грант № 19-014-00042 (Латинская Америка в новом мировом порядке: перспективы и проблемы).

Автор благодарит Владимира Рувинского и Андреса Сербина за плодотворные обсуждения темы статьи.

Для цитирования: Jeifets V.L. Dreaming on Latin America: Reflections on Russian Diplomacy in the Region // Вестник Российского университета дружбы народов. Серия: Международные отношения. 2020. Т. 20. № 3. C. 521 -533. DOI: $10.22363 / 2313-0660-2020-20-3-521-533$

\section{Introduction}

The almost thirty years of Russia's policy towards Latin America and the Caribbean (LAC) were marked with different features. Since the disintegration of the USSR in 1991 Moscow tried to reformulate its vision of the region starting from complete indifference to the local politics and economics. Later, the need to find new allies in new competition with the Western countries made Russia to reactivate its diplomacy in LAC (some experts even talk about "Russian bear's return").

The coming back to Latin America is, rather, uneasy, and serious achievements of the first two decades of 21 st century now seem to bring new problems for the Kremlin. The political reconfiguration of Latin American political landscape and the end of so called "Left-Wing turn" not only affected negatively the independent line of Latin America's diplomacy, but also impacted Russia's relations with the continent. The fall in the price of oil has its dramatic effect on Moscow's main Latin American political partner, Venezuela, and the systemic crisis puts on question not only the ability of Nicolas Maduro to survive but also Russia's ability to maintain as an influential actor. In Argentina, although the neo-Peronists managed to return to the presidential office, there is yet no sign of their readiness to form a new "left-wing belt" of Latin America friendly to Russia. Brazil, the biggest Russian trade partner at the continent and one of the BRICS members, is still staying at the crossroads of its foreign policy without taking clear stand between alliance with Washington or continuation of independent foreign policy.

\section{The Origins of Russia's Policy in Latin America}

The long existing Russian relations with LAC countries were largely formal throughout 19th-20th centuries, and there was no huge volume of trade (with some exceptions in the cases of Cuba and Argentina). The majority of ties were politically determined (as it was with Mexico, the first country to reestablish diplomatic relations with the USSR in 1924, or Cuba which converted into the local fortress of Communism since the triumph of Fidel Castro's revolution).

One basic feature of Russian diplomacy was established already in the Soviet times: the readiness to combine political interests and economic benefits. While Moscow broke off the relations with Chile after the coup d'état of 1973, 
it maintained trade with Argentinean military government for years [Jeifets, Khadorich, Leksyutina 2018: 215-216].

Following the collapse of the USSR, Russia redirected its policy toward the Western bloc of countries cutting the main part of commercial and political ties with LAC; Cuba was the main and dramatic example of this new policy [Davydov 2005: 491-496]. Even when Russia started to reorient its policy taking anti-US stand, the LAC was not the main priority for the Kremlin. The treaties signed during Russian Foreign Minister Evgeny Primakov's visit to the region in 1996-1997 were never fully implemented. However, E. Primakov declared for the first time that relations with the LAC were part of a new independent foreign policy [Bain 2008: 129-130].

Moscow's more active engagement with LAC may be explained by the intention to provide political support for Russian energy and military-industrial companies ${ }^{1}$. Originally, Russian interests in the region were basically economic ones. Step by step, the situation was changing since E. Primakov had formulated the concept of a multipolar world and since President Vladimir Putin began to express Moscow's dissatisfaction with the existing system of international relations) $)^{2}$. Russia was especially interested in LAC countries as more active and independent international actor since the Rio Group denounced NATO's bombing of Yugoslavia and since Chile and Mexico (being the nonpermanent members of the United Nations Security Council in 2003) rejected the British-US draft resolution authorizing an armed action in Iraq [Davydov 2009: 203].

From Moscow's perspective, Latin America is a key geopolitical region (with Brazil's particularly important role due to its claim for a permanent seat on the UNSC and its membership

1 Rouvinski V. Russian Engagement in the Western Hemisphere // Hearings before the House Committee on Foreign affairs. Washington, DC: US Government Publishing Office, 2015. P. 21.

2 Putin V. Speech at the Munich Conference on Security Policy // The President of Russia official website. February 10, 2007. URL: http://kremlin.ru/events/ president/transcripts/24034 (accessed: 06.03.2018). (In Russian). in BRICS). Moscow was, rather, satisfied by the words by the Ecuadoran Minister for Foreign Affairs Maria Fernanda Espinosa who claimed for "multipolar world" as a "fortress for regional blocs and multilateral system as a whole ${ }^{3}$. The President of Bolivia (until November of 2019) Evo Morales affirmed that the South American nations needed cooperation with Moscow with a purpose to secure independence of the continent ${ }^{4}$.

In 2008, the Russian Federation foreign policy concept declared a "strategic partnership with Brazil" and the broadening of cooperation with Argentina, Mexico, Cuba, and Venezuela (in the next version of the document, Nicaragua was added). As Russia's foreign minister, Sergei Lavrov, noted, his country and the LAC nations were seeking the supremacy of international law and the strengthening of multilateral mechanisms ${ }^{5}$. Nevertheless, one shouldn't exaggerate the place of the LAC in Moscow's priorities. Russia's 2013 Foreign Policy concept placed the LAC after North Korea, Mongolia, and Afghanistan (only African countries followed Latin America $)^{6}$. The latest edition of Russia's Foreign Policy concept (2016) pays even less attention to the region, the only reference to the LAC country (Brazil) is made in

${ }^{3}$ La canciller de Ecuador fija la paz como el primer objetivo de la política exterior // El Economista. 19.01.2018. URL: http://www.eleconomistaamerica.cl/ politica-eAm/noticias/8877849/01/18/La-canciller-deEcuador-fija-la-paz-como-el-primer-objetivo-de-lapolitica-exterior.html (accessed: 12.12.2018).

${ }^{4}$ Evo Morales visita a Putin y avanza con Rusia en la cooperación tecnológica y militar // Nodal.Am. 14.06.2018. URL: http://www.nodal.am/2018/06/evo-yputin-hablaron-sobre-cooperacion-bilateral-y-rusia-pidioinformacion-sobre-el-tren-bioceanico/ (accessed: 11.12.2018).

${ }^{5}$ Russian Minister of Foreign Affairs Sergey Lavrov Interview with RIA Novosti on Russian Relations with the Countries of Latin America and the Caribbean Basin // The Ministry of Foreign Affairs of the Russian Federation. November 17, 2008. URL: https://www.mid.ru/en/ foreign_policy/news/-/asset_publisher/cKNonkJE02Bw/ content/id/316778 (accessed: 24.02.2018).

${ }^{6}$ The Foreign Policy Concept of the Russian Federation (approved by the President of the Russian Federation V. Putin on February 12, 2013) // The Ministry of Foreign Affairs of the Russian Federation. URL: https://www.mid.ru/ en/foreign_policy/official_documents/-/asset_publisher/ CptICkB6BZ29/content/id/122186 (accessed: 11.05.2019). 
connection with BRICS group and not because of the "strategic alliance" . Up to the day Russia doesn't have special strategy for Latin America and is mostly reacting to significant changes in LAC countries without analyzing seriously the perspectives.

\section{What Kind of Return?}

Although Western media are full of articles about "Russia's return", there is no simple reedition of the Soviet pattern of ideological presence in LAC. Moscow tends to develop relations on a bilateral basis, but it also strongly interested in cooperation with regional trade and political blocks such as Community of Latin American and Caribbean countries (CELAC), Mercosur, ALBA, Pacific alliance, etc. ${ }^{9}$ It is worth to mention that Moscow seeks partnership and trade relations with many countries, and these relations in many cases are not depending directly from political attitudes. Since Evgeny Primakov's visit Russia is developing contacts and trade with Brazil and Colombia (both were not Moscow's partners in the epoch of the USSR); Russian-Argentinean trade was not impacted negatively because of political shifts in Argentina in 2015-2019, etc.

Russia's respect for the sovereignty of LAC countries may be considered as significant feature of its new policy. While Dilma Rousseff (considered in Moscow as one of the close allies) was being impeached, the Russian Ministry for

\footnotetext{
7 Foreign Policy Concept of the Russian Federation (approved by President of the Russian Federation Vladimir Putin on November 30, 2016) // The Ministry of Foreign Affairs of the Russian Federation. December 1, 2016. URL: www.mid.ru/foreign_policy/news/-/asset_publisher/ cKNonkJE02Bw/content/id/2542248?p_p_id=101_INSTA NCE_cKNonkJE02Bw\&_101_INSTANCE_cKNonkJE02 Bw_languageId=en_GB (accessed: 24.02.2018).

$\overline{8}$ Chaguaceda $\overline{\mathrm{A}}$. The Bear Comes to the West // The Global Americans. March 20, 2019. URL: https://theglobalamericans.org/2019/03/the-bear-comes-tothe-west-the-russian-agenda-in-latin-america/ (accessed: 12.02.2020).

9 The Director of Latin American Department of MFA of Russia A.V. Schetinin's Interview to TASS // The Ministry of Foreign Affairs of the Russian Federation. February 9, 2017. URL: www.mid.ru/about/professional holiday/news/-/asset_publisher/I5UF6lkPfgKO/content/id/ 2637694 (accessed: 13.01.2018). (In Russian).
}

Foreign Affairs (MFA) emphasized the country's compliance with national legal framework and refused to interfere ${ }^{10}$. Quite similar attitude was taken in autumn of 2019 when Bolivian President Evo Morales had to resign after the elections declared as fraudulent. While Moscow affirmed that the events in Bolivia "were reminiscent of a coup", it made clear that whole the issue was Bolivia's internal affair, but added that Jeanine Añez would be accepted as President ad Interim, called for new elections, and explained that Russia's "recognition or nonrecognition of her in this position was not an issue" 11.

However, the geopolitical concerns form unalienable part of Russian policy in LAC. Moscow's policy is very pragmatic and it is often trying to benefit from tensions between a number of LAC countries and Washington. These reasons aren't ideological, but geopolitical ones. Moscow never supported directly the experiments of the Bolivarian socialism in Venezuela and Bolivia and maintained its own course toward Liberal economic model despite political alliance with Chavez and Morales' governments [Pavlova 2011: 57-66].

During and after the short war with Georgia in the Southern Caucasus Russia never received help from its Eurasian allies; neither Belorussia neither Kazakhstan recognized the independence of ex-Georgian provinces Abkhazia and Southern Ossetia. On the contrary, Nicaragua and Venezuela became one of the first countries to support Moscow's stand. Cuba's attitude was something more cautious. Despite the statement of Fidel Castro over the "illegal actions" of

${ }^{10}$ Comment by the Information and Press Department on the Decision of Brazil's Senate to Remove President Dilma Rousseff from Office // The Ministry of Foreign Affairs of the Russian Federation. September 1, 2016. URL: https://www.mid.ru/ru/kommentarii/-/asset publisher/

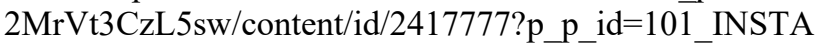
NCE_2MrVt3CzL5sw\&_101_INSTANCE_2MrVt3CzL5s w_languageId=en_GB (accessed: 24.02.2018).

11 Russian Deputy Foreign Minister Sergey Ryabkov answers a question from Prensa Latina news agency // The Ministry of Foreign Affairs of the Russian Federation. November 14, 2019. URL: https://www.mid.ru/en/foreign policy/news/-/asset_publisher/cKNonkJE02Bw/content/id/ 3899712 (accessed: 24.02.2020). 
Georgian "militants", and the declaration of the legitimacy of Russia's intervention ${ }^{12}$, Havana did not consider offering the new states any diplomatic recognition.

As the new Cold War was already a possible perspective, Moscow was seeking desperately for allies, and the Western Hemisphere gave a perfect chance to do it. In November 2008, President Dmitry Medvedev visited Peru, Brazil, Venezuela, and Cuba, and called Latin American countries "friends, with whom Russia maintains special relations"13. The ties with LAC were upgraded during visits made by other Russian officials in the following years.

In November 2008, a squadron of Russian naval ships and two Russian strategic bombers were sent to the Western hemisphere to take part in joint exercises with Venezuela being that the first military activity of Moscow in the region since the end of the Cold War [Weitz 2010: 33]. Similar "friendly visit" was made to Nicaragua in spring of 2013. Neither of these activities had military significance, nevertheless Moscow demonstrated readiness to "return to Latin America". While Washington was increasing its activity in Russia's "Near Abroad", Moscow definitely was doing the same, showing its abilities to arrive to the Caribbean.

The 2014 Ukraine crisis and the sanctions imposed on Russia by the US and the EU increased even more the Kremlin's willingness to expand its presence in LAC. On March 27, 2014 Cuba, Bolivia, Venezuela, and Nicaragua were among the eleven countries that voted against draft resolution A/68/L.39 (condemning Russia's actions in the Crimea) at the UN General Assembly. Even most important matter for Moscow was the opinion of Brazil, Argentina, and Mexico, the largest economies in the region, and two of them abstained at the United Nations General Assembly (UNGA). No Latin American government supported the imposition of sanctions against Russia (generally, Latin American countries referred to the necessity to

12 Castro F. Carne de Cañón para el Mercado. URL: http:/www.fidelcastro.cu/es/articulos/carne-de-canonpara-el-mercado (accessed: 09.05.2019).

13 To the Friend Chavez // Rossiyskaya Gazeta. November 28, 2008. (In Russian). approve such sanctions in the UN), and Evo Morales even called sanctions "economic terrorism"14. The subsequent voting at the UNGA confirmed that Latin American attitudes on the crisis in the Ukraine remain generally unchanged.

LAC countries often support Russia's international initiatives within the framework of different international organizations. Russia, Venezuela, Uruguay, China and some other countries created a strong group of associates on human rights issues that has been working within the Security Council to ensure an equal and respectful dialogue on all aspects of the topic. Some LAC countries took stands similar to Moscow's one in Syria crisis, etc. In turn, Moscow has also offered its support to LAC countries (to Brazil's claims for a permanent seat on the Security Council and to Argentina's claim against the Great Britain over the Falkland Islands).

One should agree with V. Rouvinski about inaccuracy of the term "return" since the current Russian aims only partially match those pursued by the USSR ${ }^{15}$. Moscow would like to benefit from the growing weight of LAC countries in world issues and is trying to formulate a new policy combining trade, political, and geopolitical reasons. Additional reason for increasing ties with Latin America is purely domestic one: the Kremlin has got a perfect possibility to show that Russia obtained new allies.

This Russian policy in Latin America has objective limits of cooperation. While the leftwing regimes were ready to both economic and political cooperation, the right-center and rightwing governments (and even moderate leftwingers) perceive Russia's presence in the region as a basis for trade and investment and are not so eager to cooperate in the issues of international

14 US Sanctions against Russia Is Economic Terrorism - Morales to RT // RT. October 14, 2014. URL: www.rt.com/news/195736-bolivia-moralessanctionsrussia-waiter/ (accessed: 12.05.2019).

15 Rouvinski V. Russian Engagement in the Western Hemisphere // Hearings before the House Committee on Foreign affairs. Washington, DC: US Government Publishing Office, 2015. 
political agenda. It is impossible to expect a kind of political alliance between Moscow and the current left-center governments of Mexico and Argentina.

\section{Trade and Cooperation}

Since the collapse of the USSR, trade and cooperation in some industrial sectors were considered by Moscow as one of the priorities. There has been some success in this score, with Venezuela purchasing Russian arms for some billion dollars between 2001 and $2013^{16}$. Military equipment has also been sold to Brazil, Colombia, Ecuador, Peru, and Bolivia, while Mexico has purchased a number of helicopters for its police forces.

Russian-Venezuelan relations were developing vastly during Hugo Chávez presidency (1999-2013) including not only military and technical cooperation (MTC) but also oil and gas area. Later, political cooperation was added as $\mathrm{H}$. Chávez repeatedly referred to the "revival of Russia"" . High-level diplomacy was activated as a means of demonstrating Russia's gratitude for its support of Moscow's foreign policy. In 2013 Venezuela purchased Russian mobile anti-missile system S-300VM able to defend the country from the possible US attacks.

Nicaragua is another case of activation of MTC as a gratitude for political support. Moscow has supplied Nicaragua with a wide array of military equipment, launched a new training center for Mi-17V-5 helicopter operators, and opened a Global Navigation Satellite System in 2017. Even more important was the inauguration of a center for training policemen from all over Central America. It is still unclear if this center is an attempt to displace US counter-narcotics efforts in the hemisphere [Farah, Reyes 2015: 113] or it is a

16 Berman I. Russia Pivots toward Cuba, Venezuela, Nicaragua // The Washington Times. March 26, 2014. URL: $\quad$ www.washingtontimes.com/news/2014/mar/26/ berman-russia-pivots-toward-latin-america (accessed: 05.06.2019). It is necessary to mention, however, that great part of these purchases was due to Russian loans.

${ }^{17}$ Presidente venezolano Hugo Chávez llegó a Rusia a comprar armas // La Nación. 22.07.2008. legal cover for military activities. Such volume of MTC was immediately explained by some experts as military competition with the U.S. and as an intent to convert LAC countries into consolidated political and military bloc against the U.S. hegemony [Blank 2009: 10, 22; Shuya 2019: 19-28]. We don't share such approach: although geopolitical reasons are important for Moscow, Russia as one of the biggest armssellers is also seeking new markets.

Cuban case is especial one given the old Soviet traditions of cooperation and strategic position of the island near the U.S. frontier. During his visit to Havana in 2014, Russia's President Vladimir Putin confirmed the write-off of $90 \%$ of Cuba's enormous debt to the USSR and expressed Moscow's commercial interests in helping establish a major transport hub on the island ${ }^{18}$. These declarations became an apparent attempt to restore Russia's presence on the island, especially in view of growing Chinese presence in Cuba and in the circumstances of possible U.S.-Cuban rapprochement. Neither Russia nor Cuba are ready to restore full-scale MTC cooperation of the Soviet epoch, however, both countries agreed on purchase of some Mi-17 helicopters and joint construction of thermal power plants; Moscow also has plans to create in Cuba a center for repairing helicopters sold to various LAC countries. The Cubans, in turn, cannot but reckon with the possibility of a change of government in Caracas which will put an end to the supplies with cheap oil. That is why Cubans have intensified cooperation with Russian and Chinese companies in the field of oil exploration seeking how to substitute Venezuela in case of necessity.

Moscow doesn't limit MTC to the politically close countries. For example, Peru is still buying Russian-made military equipment, and Colombia once purchased Russian helicopters during Ernesto Samper presidency in the 1990s. A new deal has been under discussion since 2017, however, Russian-Venezuelan alliance is deteriorating seriously Colombo-

\footnotetext{
${ }^{18}$ Putin V. Press Statements Following Russian-Cuban Talks // The President of Russia official website. July 11, 2014. URL: en.kremlin.ru/events/president/transcripts/ 46201 (accessed: 28.05.2019).
} 
Russian relations, and it is difficult to imagine new purchases of military machines. Some agreements on sending of Russian missilesystems "IGLA" and "Pantsir-S1" to Brazil were reached in $2013^{19}$, however, the contract was suspended in 2017 and the government of M. Temer explained that Brazil was cutting its military expenditures.

Moscow's trade with LAC countries increased from 2.2 billion USD in 2000 to 14.081 billion USD in 2019. The best numbers were shown in 2011 and 2013 (17.2 and 18.8 billion USD respectively); however, the general trade of volume is recovering after serious fall (caused by the economic crisis in Russia and LAC countries) in 2015-2016 ${ }^{20} .2011$ and 2013 were the best years for Russian exportation (with 7.8 and 8.2 billion USD respectively), nevertheless, the exportation is always less than importation from the LAC countries, and after some years of recovering, it fell once more to the level of $2014^{21}$. The conquest of LAC markets it is still a challenge for Moscow.

Formally Russia maintains trade relations with almost all LAC countries, but, in effect, almost third part of this trade is accumulated by Brazil, followed by Mexico, Argentina, and Ecuador. The volume of trade with Venezuela became now invisible due to the collapse of economy of this Caribbean country; however, Russia managed to increase drastically level of its investments in local oil and gas sector. In 2016-2018, Rosneft has invested 14 billion USD in Venezuelan oil and gas sector. Moscow also contributed to creation of cryptocurrency, the petro. In 2019 Rosneft became the first and only Russian company exempted from paying VAT in Venezuela ${ }^{22}$.

${ }^{19}$ Lima C. Brasil inicia oficialmente negociações para compra do PANTSIR-S1 e IGLA // Defensa Aérea \& Naval. 05.09.2013. URL: http://www.defesaaereanaval. com.br/?p=27829 (accessed: 17.12.2017).

20 The data are calculated by the author using the UN COMTRADE statistics until January, 2020 (ITC Trademap. URL: https://www.trademap.org/Bilateral TS.aspx?nvpm=1|643|||15|TOTAL || $2|1| 1|1| 2|1| 1|1| 1 \mid 1$ (accessed: 17.02.2020)).

${ }^{21}$ Ibid.

22 Agreement between the Russian Federation and the Bolivarian Republic of Venezuela on cooperation in the
The importance of some LAC countries for Russia on selected commodities is great: Brazil is the largest Russian export market for fertilizers, the largest import market for meat and tobacco and the second largest for sugars and sugar confectionary. Ecuador is Russia's biggest supplier of fruits, while Paraguay has become one of Russia's main beef suppliers. LAC countries purchase about one third of special machinery exported by Russia and about $11 \%$ of its radio electronics. The structure of Russian export didn't change seriously for years and it consists mostly of chemicals, fuels, metals and - in some cases - arms, machinery and electronics (although there is certain growth in this sector for Argentina, Paraguay, Brazil, and Cuba).

Russia and LAC countries often apply antidumping measures to bilateral trade (the case of Brazilian meat and Russian steel, etc.). Moscow proved unable to benefit from the economic sanctions imposed on Russia by the Western countries and to replace Western commodities with LAC production as it was expected by experts $^{23}$. Some new agreements on food supplies were reached with Mexico, Brazil, Peru, Paraguay, and Uruguay in 2015, however, in 2016 the volume of food trade decreased drastically $^{24}$. The reasons of failure to reorient LAC food producer into Russian markets were as follows: growing demand in China, low exchange rate of Russian and some Latin American currencies, and, last but not least, Moscow was not able to disappear its own custom restrictions.

Russia made investments into the oil and gas industries in Venezuela, Argentina, and Peru; "RUSAL" is one of the biggest investors into the extraction of bauxites in Guyana; Rosatom is

implementation of joint strategic projects (as amended on 10 July 2019). URL: http://docs.cntd.ru/document/ 902178639 (accessed: 17.02.2020). (In Russian).

23 Yakovlev P.P. Russia and Latin America in the context of Western sanctions // Geopolitica.ru. March 11, 2015. URL: https://www.geopolitica.ru/article/rossiya-ilatinskaya-amerika-na-fone-zapadnyh-sankciy\#.VSgo3caMgUM (accessed: 12.05.2017). (In Russian).

${ }^{24}$ The Latin American exportation of meat to Russia is decreasing // Regnum. October 13, 2015. URL: https://regnum.ru/news/1990477.html (accessed: 12.05.2017). (In Russian). 
contributing into the Argentina's nuclear plants construction. Russian businessmen participate in construction and development of hydroelectric plants in Argentina, Ecuador, Chile, Brazil and Mexico. The railroads, car industry, airplanes, are another area of cooperation.

The high level of political representation of Russia in the region still does not correspond to a modest level of trade and investments. Certain ideologization (even if it is only rhetoric) of relations with Venezuela, Cuba, and Bolivia led to almost complete absence of relationship with opposition forces. Such circumstances put Russian business under serious risks in case of political changes. It is not accidental, that new government of Bolivia has already declared possibility to reconsider agreements signed with Rosatom years ago.

\section{Chinese Challenges for Moscow}

Over the last decade Beijing has become a key Latin American partner. Pursuing a "multidimensional strategy of extreme pragmatism" [Serbin 2016b] based on the primacy of economic considerations ${ }^{25}$, Beijing imports raw materials from the region and offers finished commodities, arms and technology in return. In some key positions China definitely wins Russia. While Moscow only managed to triple its trade with LAC in the 21st century, China's trade with the region grew of more than seventeen over the same period [Serbin 2016a] and it became the largest export market for Brazil and Chile, and the second largest for Peru, Cuba, and Costa $\mathrm{Rica}^{26}$. China is promoting free-trade area agreements on bilateral basis, while Russia prefers to act through the integration groups, thus, depending a lot from controversies inside groups like Mercosur, etc.

China has already become a key LAC financial partner having invested more than 110

${ }^{25}$ Full text of China's Policy Paper on Latin America and the Caribbean // Xinhua. November 24, 2016. URL: http://english.www.gov.cn/archive/white_paper/2016/11/2 4/content_281475499069158.htm (accessed: 12.01.2020).

${ }^{26}$ Heine J. A Chinese Garden in America's Backyard? Sino-LAC links in 2018 // Global Times. December 27, 2018. URL: http://www.globaltimes.cn/content/1133768. shtml (accessed: 25.01.2020). billion USD in the region since 2003. By 2024, the volume of trade between China and LAC is expected to grow to 500 billion USD, with Chinese investments growing to 250 billion USD. To promote cooperation with LAC, the China - CELAC Cooperation Fund was created with an investment of 5 billion USD ${ }^{27}$. While Moscow only invested in some four or five LAC countries, Chinese businessmen are investing almost everywhere. Russian enterprises as a rule do not have sufficient support from their mother country.

Beijing is much more active in working with Chinese diaspora in LAC comparing with the same activities carried out by Moscow towards Russian communities [Serbin 2016a]. While Moscow normally limits its contacts with ruling parties, China, by contrast, maintains ties with 90 political parties and organizations, and cross-party groups [Sudarev 2015: 204].

Russia and China are at the same time partners and competitors in LAC countries. Beijing would like to get more participation in the areas considered by Moscow as its "natural field of cooperation" (such as nuclear energy, thermal plants, satellites, oil and gas exploration, etc.). While China, Russia and Brazil are members of BRICS, and both Moscow and Beijing are talking about strategic partnership with the South-American giant, the Brazilian media pay more attention to the cooperation with China forgetting about Moscow ${ }^{28}$. As P. Yakovlev pointed out, the decrease in Russian-Brazilian trade was overcome in 2017 [Yakovlev 2017: 16-17], and Russian hi-tech companies even expanded its activities in Brazilian markets, nevertheless, China is more successful in Brazilian markets.

In 2016-2020, both Moscow and Beijing have helped to Nicolas Maduro government

${ }^{27}$ Cachinero J. América Latina y China: ¿el fin de la adicción a las 'commodities'? // Es Global. 30.12.2015. URL: http://www.esglobal.org/america-latina-y-china-el-finde-la-adiccion-a-las-commodities/ (accessed: 20.09.2017).

${ }^{28}$ Ehrmann E. Russia and Brazil - What Will Come After Rousseff? // Russian International Affairs Council. April 14, 2016. URL: https://russiancouncil.ru/en/ analytics-and-comments/analytics/braziliya-i-rossiya-chtobudet-posle-russeff/ (accessed: 18.11.2017). 
economically in the context of its growing isolation [Gurganus 2018], and several times supported Venezuelan regime in the UN Security Council. However, since 2016 there are certain differences in Russian and Chinese diplomacies in Venezuela. While Beijing tried to find an arrangement with Venezuelan opposition (in order to secure its own investments), Moscow is persisting in its hard-line of support to N. Maduro considering him as only legitimate negotiator ${ }^{29}$.

China until recently managed to be more successful in penetration to Venezuelan oil and gas industry. As Beijing was ready to provide Caracas with bigger sums of money, this support was crucial for Nicolas Maduro government. And only when the danger of U.S. intervention seemed probable after the declaration of Presidency ad Interim by Juan Guaidó, N. Maduro turned definitely to Moscow. Venezuelan President still hopes to get military support in case of eventual conflict with Washington $^{30}$, and China would highly unlikely provide this type of help.

Generally, the Chinese-Russian competition yet becomes open only in limited number of cases. The main part of Chinese investments is devoted to the segments of extracting industries while Russia is not so interested in obtaining minerals from LAC. The membership in BRICS also serves to coordination of activities; at Summit of BRICS in Brasilia in November 2019, China and Moscow made a joint front opposing to Brazilian plans to discuss Venezuelan issue and defending Maduro's government. The New Development bank of BRICS is devoted to be a tool of cooperation of both China and Russia in Latin America as also in other areas.

China is ready sometimes to give a room for Russian competitors in some megaprojects (the

29 Ellis E. China, Russia Increase Leverage in Venezuela Amid Crisis // The Global Americans. September 14, 2017. URL: https://theglobalamericans.org/ 2017/09/china-russia-increase-leverage-venezuela-amidcrisis/. See also: [Rozental 2016: 42].

${ }^{30}$ Chaguaceda A. The Bear Comes to the West // The Global Americans. March 20, 2019. URL: https://theglobalamericans.org/2019/03/the-bear-comes-tothe-west-the-russian-agenda-in-latin-america/ (accessed: 12.02.2020). plan to build new inter-Oceanic channel in Nicaragua was one of the possible areas for cooperation: while Chinese and Nicaraguan specialists would be constructing the infrastructure, Russians should be engaged in security issues). However, this project lost its importance due to the bankruptcy of Chinese investor $^{31}$ and also because of ChinesePanamanian rapprochement ${ }^{32}$.

The main challenge in Chinese-Russian cooperation for Moscow is that Russia wouldn't like to be converted in the minor partner of Beijing; on the contrary, it would like to use China for building a polycentric and multipolar world.

\section{Venezuela, a Dead End or Possibility for Moscow?}

For years Moscow was supporting Venezuelan government. In November 2017, Moscow agreed to refinance 3.15 billion USD debt in bilateral loans and delay almost all payments until after 2023 [Gurganus 2018], thus giving Caracas additional breathing. In return, Russia obtained some preferences in access to Venezuela's oil and gas reserves being Rosneft the main actor in these plans. State-owned PDVSA has used Rosneft for deliveries of Venezuelan oil abroad.

However, the permanent Venezuelan economic turmoil turned to be systemic crisis in the recent years, and since almost 60 countries dropped its recognition to Nicolas Maduro's government giving it, in contrast, to the speaker of National Assembly Juan Guaidó, there is serious and dangerous challenge for Moscow.

Russia wouldn't like to lose an ally, although this partner has no regional influence and credibility. Even more important, Moscow can't show weakness and its retreat in Venezuela can be considered as a sign of losing influence.

31 Intercidumbres financieras desvanecen sueño de canal en Nicaragua // El Financiero (San José, Costa Rica). 21.02.2018.

32 Ellis E. Panama's recognition of the PRC // Global Americans. June 13, 2017. URL: theglobalamericans.org/ 2017/06/panamas-recognition-prc-strategic-implicationsrecommendations-u-s/ (accessed: 20.09.2018). 
However, the persistence in maintaining support for Maduro's government is affecting negatively Russian relations with many other LAC countries who consider Venezuelan president a dictator.

During the crisis Russia was able to mobilize diverse tools of engagement: Moscow was sending groups of militaries, used its veto power in the UN Security Council as also provided Maduro's government with facilities for oil and finances transportation. Nevertheless, Moscow found itself at dilemma: continuity of alliance with Chavist government would put in risk Russian investments in Venezuelan oil and gas sector (some billion USD) and its political and economic links in the region, but the exit strategy might affect all Russian foreign policy in the world and its relations with allies it still has. Additionally, Russian benefits from the Venezuelan oil resources are also at risk, as many local companies were sanctioned by the $\mathrm{US}^{33}$. This may explain the Rosneft decision to sell its properties in this Caribbean country to Russian government. Moscow founded new enterprise, Roszarubezhneft with a purpose to deliver ex-Rosneft properties in Venezuela to it and maintain formal presence in this country on the basis of the structures which are not (at least, yet) supposed to be sanctioned by the U.S. authorities. At the same time, all economic activity of Roszarubezhneft at the moment tends to decrease due to the collapse of Venezuelan oil industry and because of difficulties with selling Venezuelan oil to other countries. Additionally, there is a risk of nationalization of all these properties in case of change of government in Venezuela.

The failure of the blitzkrieg organized by Washington in January 2019 (when Guaidó was auto-proclaimed as Interim President) and its inability to make Nicolas Maduro resign opens some (still unclear) perspectives to Moscow. Russia, as also China and Mexico, was insisting in the necessity of peaceful, legal and local resolution of the Venezuelan crisis and on the necessity of direct dialogue between N. Maduro and opposition. Up to the moment, all such intents failed.

\footnotetext{
${ }^{33}$ Hess M. Is the Kremlin Tired of Venezuela? // The Moscow Times. September 26, 2019.
}

A lot depends from Moscow, Washington and Beijing. Moscow is, most probably, evaluating benefits and risks and possibility to use the complicated Venezuelan situation as an opportunity to reshape the nature of its engagement with LAC. It is worth to note that throughout 2019, Moscow didn't offer Venezuela any new loan or prepayments of oil, but only help in military logistics.

If three superpowers come to some arrangement (which can include formation of transition government, elections attended by international observers and multilateral guarantees for local political actors and regional extra-hemispheric actors influential in Venezuela), everything would change in the Caribbean. Up to the moment, there are no signs of such rapprochement, and no one of three countries is going to make first step without getting serious guarantees. Washington wouldn't like to start a military intervention and to face possible counteraction of Russian military defending N. Maduro, but Moscow also is trying to escape this scenario and doesn't want to be engaged into a war. While Washington reluctantly tolerates Russian intervention in the geographically-distant Syria, it would not accept such a move in its "backyard". If there is a possibility to resolve Venezuelan crisis due to common efforts, is still an enigma.

\section{Are There Good Prospects for Russia in LAC?}

While the relationship between Moscow and the West entered into a kind of "New Cold War", Russia tried to seek new partners in politics as also in business issues, and LAC is considered as proper area for it. The path wouldn't be easy, as Russia has to compete not only with the US, but also with China and some other emerging powers (India and Turkey, for example) $)^{34}$. As for the LAC, Russian and Chinese presence in the region, "introduces an opportunity for CELAC

\footnotetext{
${ }^{34}$ China y Latinoamerica sellan una alianza que quiere ser un modelo de cooperacion // Gob.pe. 01.09.2015. URL: https://www.gob.pe/institucion/apci/noticias/111393china-y-latinoamerica-sellan-una-alianza-que-quiere-serun-modelo-de-cooperacion (accessed: 18.11.2019).
} 
countries to establish business relations beyond the United States and Europe" [Sitenko 2016].

Russian President Vladimir Putin's selfsufficiency and foreign activity, and his ability to react promptly, contribute towards the effectiveness of Moscow's diplomacy. However, the personification of foreign policy generates stereotypes about political realities in Russia, making some people believe that presidential political will is the only consideration in foreign policy-making, obscuring the real facts and real national interests.

A good example of the use of Moscow's "soft power" in Latin America was the implementation of a project to deploy the Spanish-language broadcasting of Russia Today (RT) and Sputnik in the LAC region. RT declared the task of becoming an alternative source of information and managed to find its niche in the local audience and a higher rate of increase in the number of viewers compared to other foreign media. The importance of RT can be demonstrated by the fact that the first international interview given by the current Argentina's president A. Fernández was made in this TV channel. The content of RT programs is often a mirror image of Western criticism of Russia (allegations of corruption, violation of human rights and international law - all the topics that concern the Latin American audience); however, the factual series cited during the broadcasting indicates the prevalence of these problems in the West [Rouvinski 2017].

The involvement of the Russian Orthodox Church in the matter of Moscow's contacts in LAC countries is another new feature. In February 2016, a landmark meeting between Pope Francisco and the Russian Patriarchy Cyril in Havana took place. Cuba turned out to be an ideal place for this, showing at the same time the continuity of the former USSR policy towards this country, the expansion of contacts with
Havana after the start of US-Cuban normalization, and the fact that Moscow seriously takes the role of Latin American states as an international actor.

Visits to the patriarch became an almost unchanged part of the routine during trips of Latin American leaders to the Russian Federation demonstrating the symbolic role that the Russian Orthodox Church plays today in the postimperial Russia. Moscow, in turn, is ready to advance the interests of the Russian Orthodox Church in Latin America, since expanding ties with the Russian diaspora is a common interest of the church and the state.

Modern Russian policy in the region is often engaged in propaganda of "universal traditional values" seeking support among part of some segments of Latin American society. Nevertheless, the left-wing's support for "traditional values" cannot be unlimited, many of them (like Uruguayan, for example) have long advocated for the expansion of human rights, and the articulation of theses on "conservative values" wouldn't cause much enthusiasm.

To sum up, there is no doubt that Russia's policy towards the region tends to pragmatism. However, from time to time Russian authorities neglect economic advisability, despite the fact that they do not possess enough resources to match the Soviet capabilities. The old problems remain a major obstacle to establishing a new dynamism. Even the general comparison shows that our partners in BRICS, China and India, managed to establish better volume of trade and investment with Brazil and with LAC countries as a whole than Moscow does.

Moscow still has possibilities for developing its ties with LAC, however, if Russia wouldn't be able to reshape some lines of its Latin American diplomacy, it would come to re-edition of the Soviet policy in that region, with the same results.

Received / Поступила в редакцию: 10.03.2020

Accepted / Принята к публикации: 12.05.2020

\section{References}

Bain, M. (2008). Russian-Cuban Relations since 1992. Lanham, MD: Lexington.

Blank, S. (2009). Russia in Latin America: Geopolitical Games in the US's Neighborhood. Paris: IFRI. 
Davydov, V. (Eds.). (2009). Latin America in Contemporary World Affairs. Moscow: Nauka publ. (In Russian).

Davydov, V.M. (Eds.). (2005). Russia and Cuba in the Context of Economic Globalization. Moscow: ILA publ. (In Russian).

Farah, D. \& Reyes, L. (2015). Russia in Latin America: A Strategic Analysis. Prism, 5 (4), 101-117.

Gurganus, J. (2018). Russia: Playing a Geopolitical Game in Latin America. URL: https://carnegieendowment.org/ 2018/05/03/russia-playing-geopolitical-game-in-latin-america-pub-76228_(accessed: 18.12.2019).

Jeifets, V., Khadorich, L. \& Leksyutina, Y. (2018). Russia in Latin America: Renewal versus Continuity. Portuguese Journal of Social Science, 17 (2), 213-218. DOI: 10.1386/pjss.17.2.213_1

Pavlova, E. (2011). Latinoamérica y Rusia: Una aproximación ilusoria. Foreign Affairs: Latinoamérica, 11 (2), $57-66$.

Rouvinski, V. (2017). Understanding Russian Priorities in Latin America. Kennan Cable, 20. URL: https://www.wilsoncenter.org/publication/kennan-cable-no20-understanding-russian-priorities-latin-america (accessed: 18.11.2019).

Rozental, D.M. (2016). The Dragon over Caracas. Relations between China and Venezuela in the Beginning of the XXI Century. Latinskaia Amerika, 3, 39-50. (In Russian).

Serbin, A. (2016a). ¿Un nuevo ciclo del regionalismo latinoamericano en el siglo XXI? Ibero-American Studies Center, St.-Petersburg State University. URL: http://iberorus.spbu.ru/uploads/serbin.pdf (accessed: 28.02.2019).

Serbin, A. (2016b). ¿Un triángulo escaleño? América Latina y el Caribe, China y los Estados Unidos y las narrativas del nuevo ciclo. Anuario de la Integración Regional de América Latina y del Caribe, 13, 31-58.

Shuya, M. (2019). Russian Influence in Latin America: A Response to NATO. Journal of Strategic Security, 12 (2), 17-41. DOI: $10.5038 / 1944-0472.12 .2 .1727$

Sitenko, A. (2016). Latin American Vector in Russia's Foreign Policy: Identities and Interests in the RussianVenezuelan Partnership. Politics in Central Europe, 12 (2), 37-56. DOI:10.1515/pce-2016-0003

Sudarev, V. (2015). Latin America: New Geopolitical Challenges. Moscow: MGIMO-Universitet publ. (In Russian).

Weitz, R. (2010). Global Security Watch - Russia: A Reference Handbook. Santa Barbara, CA: ABC-CLIO.

Yakovlev, P.P. (2017). Russia - Latin America: A Breakthrough Strategy for Non-Primary Products Markets. Latinskaia Amerika, 12, 16-17. (In Russian).

\section{Библиографический список}

Латинская Америка в современной мировой политике / отв. ред. В.М. Давыдов. М.: Наука, 2009.

Розенталь Д.М. Дракон над Каракасом. Китайско-венесуэльские отношения в начале XXI в. // Латинская Америка. 2016. № 3. С. 39-50.

Россия и Куба в контексте экономической глобализаичи / отв. ред. В.М. Давыдов. М.: ИЛА, 2005.

Сударев В.П. Латинская Америка: новые геополитические вызовы. М.: МГИМО-Университет, 2015.

Яковлев П.П. Россия - Латинская Америка: стратегия прорыва на рынки несырьевой продукции // Латинская Америка. 2017. № 12. С. 16-17.

Bain M. Russian-Cuban Relations since 1992. Lanham, MD: Lexington, 2008.

Blank S. Russia in Latin America: Geopolitical Games in the US's Neighborhood. Paris: IFRI, 2009.

Farah D., Reyes L. Russia in Latin America: A Strategic Analysis // Prism. 2015. Vol. 5. No. 4. P. 101-117.

Gurganus J. Russia: Playing a Geopolitical Game in Latin America. 2018. URL: https://carnegieendowment.org/ 2018/05/03/russia-playing-geopolitical-game-in-latin-america-pub-76228_(accessed: 18.12.2019).

Jeifets V., Khadorich L., Leksyutina Y. Russia in Latin America: Renewal versus Continuity // Portuguese Journal of Social Science. 2018. Vol. 17. No. 2. P. 213-218. DOI: 10.1386/pjss.17.2.213_1

Pavlova E. Latinoamérica y Rusia: Una aproximación ilusoria // Foreign Affairs: Latinoamérica. 2011. Vol. 11. No. 2. P. $57-66$.

Rouvinski V. Understanding Russian Priorities in Latin America // Kennan Cable. 2017. No. 20. URL: https://www.wilsoncenter.org/publication/kennan-cable-no20-understanding-russian-priorities-latin-america (accessed: 18.11.2019).

Serbin A. ¿Un nuevo ciclo del regionalismo latinoamericano en el siglo XXI? Ibero-American Studies Center, St.-Petersburg State University. 2016. URL: http://iberorus.spbu.ru/uploads/serbin.pdf (accessed: 28.02.2019).

Serbin A. ¿Un triángulo escaleño? América Latina y el Caribe, China y los Estados Unidos y las narrativas del nuevo ciclo // Anuario de la Integración Regional de América Latina y del Caribe. 2016. No. 13. P. 31—58. 
Shuya M. Russian Influence in Latin America: A Response to NATO // Journal of Strategic Security. 2019. Vol. 12. No. 2. P. 17 -41. DOI: $10.5038 / 1944-0472.12 .2 .1727$

Sitenko A. Latin American Vector in Russia's Foreign Policy: Identities and Interests in the Russian-Venezuelan Partnership // Politics in Central Europe. 2016. Vol. 12. No. 2. P. 37-56. DOI:10.1515/pce-2016-0003

Weitz R. Global Security Watch - Russia: A Reference Handbook. Santa Barbara, CA: ABC-CLIO, 2010.

About the author: Jeifets Viktor Lazarevich - PhD, Dr. of Sc. (History), Professor, Director, Center for Ibero-American Studies, Saint-Petersburg State University (e-mail: jeifets@gmail.com).

Сведения об авторе: Хейфец Виктор Лазаревич - доктор исторических наук, профессор, директор Центра ибероамериканских исследований Санкт-Петербургского государственного университета (e-mail: jeifets@gmail.com). 